\title{
Correlation of serum homocysteine levels in pregnancy related hypertensive disorders versus normotensive pregnancies
}

\author{
Kaliki Hymavathi*, Neha Shukla, P.V. Sreeleena Madhuri
}

Department of Obstetrics and Gynecology, Narayana Medical College and Hospital, Nellore, Andhra Pradesh, India

Received: 12 December 2019

Accepted: 06 January 2020

\section{*Correspondence:}

Dr. Kaliki Hymavathi,

E-mail: dr.hymakrreddy@gmail.com

Copyright: (C) the author(s), publisher and licensee Medip Academy. This is an open-access article distributed under the terms of the Creative Commons Attribution Non-Commercial License, which permits unrestricted non-commercial use, distribution, and reproduction in any medium, provided the original work is properly cited.

\begin{abstract}
Background: Homocysteine concentrations decrease during normal pregnancy, but this does not occur in preeclampsia. In pre-eclampsia, homocysteine levels further increase with severity of pre-eclampsia. Elevated homocysteine levels can be due to genetic or multifactorial deficit or a combination of both.

Methods: The present study was conducted at department of obstetrics and gynaecology, Narayana Medical College and Hospital, Nellore. 200 pregnant (100 women with pregnancy related hypertensive disorders and 100 normotensive pregnants) recruited. Maternal serum Homocysteine levels were analyzed among women with pregnancy related hypertensive disorders and compared with normotensive pregnant. Chemiluminescence immunoassay was used for determining the Homocysteine levels.

Results: The study revealed significant elevation in the levels of homocysteine in pre-eclamptic women (17.54 \pm 5.34$)$ compared to normotensive women (7.59 \pm 1.91$)$. The study showed a strong association between serum homocysteine levels and severity of pre-eclampsia. The mean homocysteine levels in women with severe Pre-eclampsia (20.59 \pm 4.3$)$ were significantly higher than those with mild pre-eclampsia (15.17 \pm 1.9$)$. A positive correlation is found between homocysteine levels with serum uric acid and LDH demonstrating the harmful action of hyperhomocysteinemia upon the endothelium. A negative correlation is found between homocysteine levels with hemoglobin and hematocrit even though in anemic patients the hematological levels are found to be little high due to hemoconcentration. The perinatal outcome in women with raised levels of homocysteine was poor with an increased incidence of IUGR (41\%), SGA (9\%), still births (3\%) and IUD (4\%) among women with pregnancy related hypertensive disorders when compared to normotensive pregnant women.

Conclusions: Elevated homocysteine concentration injures the vascular endothelium, thereby contributing to the pathology of pregnancy related hypertensive disorders.
\end{abstract}

Keywords: Homocysteine, Pregnancy related hypertension, Perinatal outcome

\section{INTRODUCTION}

Hypertensive disorders complicate 5 to $10 \%$ of all pregnancies. $^{1}$ Along with haemorrhage and infection, it forms the deadly triad that contributes to maternal morbidity and mortality. ${ }^{2}$ Incidence of PIH in India ranges from $5 \%$ to $15 \%$. $\mathrm{PIH}$ is associated with $16 \%$ of all maternal mortality and $20 \%$ of all perinatal mortality in India. According to epidemiological evidence women with previous gestational hypertension seem to be at increased risk of cardiovascular disease, hypertension, stroke and death from ischaemic heart disease in later life 
compared with the general population. PIH develops due to pregnancy and regresses after delivery. It is a major cause of premature delivery, intrauterine growth restriction (IUGR), placental abruption, fetal death and numerous adverse pregnancy outcomes.

Though the exact cause of pre-eclampsia is still undecided, endothelial dysfunction with associated intense vasospasm has been implicated in its causation. ${ }^{2}$ Homocysteine, a sulphur containing amino acid usually decreases in gestation, either due to physiological response to the pregnancy, increase in estrogen, hemodilution from increased plasma volume or increased demand for methionine by both the mother and fetus. Homocysteine is involved in processes such as lipid peroxidation, oxidative stress and endothelial dysfunction and thereby resulting in pre-eclampsia. ${ }^{3}$

The present study is aimed at the estimation of serum homocysteine concentration in both pregnancy related hypertensive disorders and normotensive pregnant women, thereby reducing its relation in causation of preeclampsia.

Elevated homocysteine levels confer an independent and incremental risk for vascular disease, direct endothelial toxicity, failure of nitric oxide release and platelet abnormalities. Homocysteine may prove to be the missing link in the etiology of pre-eclampsia. ${ }^{3}$ Further, hyperhomocysteinemia may also be an important biological marker for adverse outcome of pregnancy and even possibly a cause of or a contributor to the complications of pregnancy. ${ }^{4}$

\section{METHODS}

This is a prospective case-control study done in the department of obstetrics and gynaecology, Narayana Medical College and Hospital, Nellore for a period of 2 years, (October 2016-October 2018).

This study was to analyze the serum levels of homocysteine among pregnant women with pregnancy related hypertensive disorders and to compare with those of normotensive pregnancies.

\section{Sample size}

A total 200 pregnant women with 100 in each Group A and Group B.

- Group A-cases: Pregnant women diagnosed with pregnancy related hypertensive disorders.

- Group B-controls: normotensive pregnant women.

\section{Inclusion criteria}

- Pregnant women with pregnancy related hypertensive disorders (gestation hypertension, preeclampsia, eclampsia and chronic hypertension)
- Normotensive pregnant women, both primigravida and multigravida with no bad obstetric history.

\section{Exclusion criteria}

- Pregnant women with H/O smoking and alcoholism

- Pregnant women with other conditions like gestational diabetes, diabetes mellitus, cardiovascular disease, chronic liver and kidney disease, anemia, multiple pregnancies and other chronic diseases that interfere with the study

- Pregnant women on antioxidant like vitamin E.

\section{Patient analysis}

Institutional ethical committee of Narayana Medical College and Hospital, Nellore, Andhra Pradesh has approved the study with the following ethical considerations:

- No bias when sample selection was done with respect to age, parity, socioeconomic status

- A written consent was taken from all subjects after explaining them, regarding the study and then they were included in the study

- The study group should not be exposed to any increased risk as a result of the study

- Confidentiality should be maintained.

All the women with pregnancy related hypertensive disorders and normotensive pregnant women attending the obstetrics department of Narayana Medical College and Hospital, were recruited into the study and control groups following detailed history and clinical examination. Apart from routine antenatal investigations specific investigations were sent related to the present study. In the present study serum homocysteine levels were measured in both study and control groups

\section{Blood sample collection}

Blood samples were collected preferably from the antecubital vein irrespective of fasting status. In cases, sample was taken after the diagnosis of pre-eclampsia or eclampsia was made immediately after admission and before initiation of antihypertensive treatment and before the delivery. All the specimens were transported to the laboratory within 30minutes of collection. After that, specimens were centrifuged for 5-7 minutes at $3000 \mathrm{rpm}$. Then clear serum was transfused in aplastic vial and stored in refrigerator until analysis. Samples were stored at $2-8{ }^{\circ} \mathrm{C}$. Chemiluminescence immunoassay was used for determining the homocysteine levels. The system used was an automated, random access, direct CLIA analyzer.

\section{Statistical analysis}

Statistical analysis was done applying students unpaired ' $t$ ' test and Pearson's correlation coefficient. The data 
obtained was analyzed using SPSS software version 17.0 to generate graphs and tables

\section{RESULTS}

One hundred pregnant women fulfilling the inclusion criteria were recruited in the study group. Among the group 65 were primigravida and 35 were multiparous women. Another 100 normal pregnant women were taken as control group among whom 75 were primigravida and 25 were multiparous women.

In the present study, the age distribution varied from 1935 years. The majority of pregnant women $46 \%$ in study group and $51 \%$ in control group were under the age group of 25-30 years. $15 \%$ of women in study group and $16 \%$ of women in control group were elderly gravida with age 30-35 years.

The mean age among the pregnant women with pregnancy related hypertensive disorder (study group) is 25.6 years and 25.93 years in normotensive pregnant women (control group) which is not significant ( $\mathrm{p}=$ $0.506)$.

The mean gestation age in women is 34.88 weeks in study group and 34.81 in control group. This shows there is no significant difference among the women with pregnancy related hypertensive disorders and normotensive pregnant women with regard to the period of gestation $(\mathrm{p}=0.777)$.

The SBP for the study group is $150.57 \pm 8.1 \mathrm{mmHg}$ and for the control group is $112.9 \pm 8.3 \mathrm{mmHg}$ with a significant $\mathrm{p}$-value $<0.0001$. This indicates that SBP is higher in PIH cases when compared to normotensive pregnant women.

The mean DBP in study group is $97.2 \pm 8.1 \mathrm{mmHg}$ and in control group is $73.57 \pm 6.7 \mathrm{mmHg}$ with a significant $\mathrm{P}$ value of $<0.0001$. These values indicate that there is a rise in the DBP among the PIH cases when compared to the normal pregnant women.

The mean arterial pressure (MAP) in the study group is $115.35 \pm 6.9 \mathrm{mmHg}$ and $86.4 \pm 4.9$ in the control group with a significant $\mathrm{p}$-value $<0.001$.

The mean serum homocysteine levels in women with pregnancy related hypertensive disorders (study group) is $17.54 \pm 5.34 \mu \mathrm{mol} / \mathrm{L}$ and in normotensive pregnant women is $7.59 \pm 1.91 \mu \mathrm{mol} / \mathrm{L}$ with a significant $\mathrm{p}$-value $<0.0001$.

The Table 1 shows the mean serum Homocysteine levels are raised as there is a raise in the systolic blood pressure among the study group with a significant p-value 0.023 . This indicates that serum homocysteine levels are directly correlated with the severity of pregnancy related hypertensive disorders.
Table 1: S. homocysteine levels and SBP in study group.

\begin{tabular}{|lll|}
\hline SBP (mmHg) & N & $\begin{array}{l}\text { Mean S. Homocysteine } \\
(\mu \mathrm{mol} / \mathrm{L})\end{array}$ \\
\hline $140-149$ & 28 & $15.33 \pm 4.27$ \\
\hline $150-159$ & 35 & $16.38 \pm 5.30$ \\
\hline $160-169$ & 36 & $20.30 \pm 5.03$ \\
\hline
\end{tabular}

P-value - 0.023 (significant).

The Table 2 depicts the direct relationship between the serum homocysteine levels and diastolic blood pressure. As the DBP raises there is a significant rise in the serum homocysteine levels with p value-0.040.

Table 2: S. homocysteine levels and DBP: study group.

\begin{tabular}{|lll|}
\hline DBP (mmHg) & N & Mean S. Homocysteine \\
\hline $90-100$ & 49 & $15.24 \pm 4.02$ \\
\hline $101-109$ & 29 & $17.51 \pm 0.78$ \\
\hline $110-119$ & 22 & $22.68 \pm 1.24$ \\
\hline
\end{tabular}

p-value - 0.040 (significant).

Table 3: Serum homocysteine levels and mean arterial pressure (map): study group.

\begin{tabular}{|lll|}
\hline MAP (mmHg) & N & $\begin{array}{l}\text { Mean S. Homocysteine } \\
(\mu \mathrm{mol} / \mathrm{L})\end{array}$ \\
\hline $100-109$ & 17 & $13.93 \pm 2.5$ \\
\hline $110-119$ & 48 & $15.70 \pm 3.7$ \\
\hline $120-129$ & 33 & $21.45 \pm 5.4$ \\
\hline $130-139$ & 2 & $27.65 \pm 2.7$ \\
\hline
\end{tabular}

$\mathrm{p}$ value-0.0001 (significant).

The MAP is in direct correlation with the levels of serum homocysteine in women with pregnancy related hypertensive disorders. As, the MAP is raised the serum homocysteine values have also raised with a significant $\mathrm{p}$ value-0.0001 (Table 3).

Table 4: Correlation between serum homocysteine levels and SBP, DBP and map in study group.

\begin{tabular}{|lll|}
\hline $\begin{array}{l}\text { Relationship } \\
\text { between }\end{array}$ & $\begin{array}{l}\text { Pearsons } \\
\text { value }\end{array}$ & $\begin{array}{l}\text { Significance p- } \\
\text { value }\end{array}$ \\
\hline $\begin{array}{l}\text { SBP and S. } \\
\text { Homocysteine }\end{array}$ & 0.311 & $0.002 \mathrm{~S}$ \\
\hline $\begin{array}{l}\text { DBP and S. } \\
\text { Homocysteine }\end{array}$ & 0.543 & $<0.0001 \mathrm{HS}$ \\
\hline $\begin{array}{l}\text { MAP and S. } \\
\text { Homocysteine }\end{array}$ & 0.832 & $<0.0001 \mathrm{HS}$ \\
\hline
\end{tabular}

S-significant, HS- highly significant.

The Table 4 shows there is a positive correlation among the levels of serum homocysteine with the systolic blood pressure values $(\mathrm{r}-0.311, \mathrm{p}=0.002)$, diastolic blood pressure values $(\mathrm{r}-0.543, \mathrm{p} \leq 0.0001)$ and mean arterial 
pressure $(\mathrm{r}-0.832, \mathrm{p} \leq 0.0001)$ among the women with regnancy related hypertensive disorders.

This indicates that serum homocysteine levels are directly correlated with the severity of pregnant related hypertensive disorders.

In the control group (normotensive pregnant women) all 100 women had serum homocysteine levels within the normal limits, where as in the study group of 100 women with pregnancy related hypertensive disorders 88 cases had elevated serum homocysteine levels which is highly statistically significant.

The mean serum homocysteine levels were 13.28 in women with chronic hypertension, 14.63 in gestational hypertension, 17.04 in women with pre-eclampsia and 27.05 in women with eclampsia.

Within the women diagnosed as pre-eclampsia in the study group, the mean serum homocysteine levels among women with mild pre-eclampsia was $15.17 \pm 1.9 \mu \mathrm{mol} / \mathrm{L}$ and with severe pre-eclampsia was $20.59 \pm 4.3 \mu \mathrm{mol} / \mathrm{L}$.

Table 5: Serum homocysteine and urine albumin in study group.

\begin{tabular}{|c|c|c|c|}
\hline \multirow{2}{*}{ Albuminuria } & \multicolumn{2}{|c|}{$\begin{array}{l}\text { S. Homocysteine } \\
\text { levels }\end{array}$} & \multirow{2}{*}{$\begin{array}{l}\text { Mean } \\
\text { Homocysteine } \\
\text { levels ( } \mu \mathrm{mol} / \mathrm{L})\end{array}$} \\
\hline & $\begin{array}{l}\text { Normal } \\
\text { (n) }\end{array}$ & $\begin{array}{l}\text { Raised } \\
\text { (n) }\end{array}$ & \\
\hline Nil & 5 & 15 & $14.64 \pm 2.7$ \\
\hline Trace & 4 & 6 & $14 \pm 3.11$ \\
\hline+1 & 2 & 21 & $16.32 \pm 2.76$ \\
\hline+2 & 0 & 30 & $17.96 \pm 4.8$ \\
\hline+3 & 1 & 16 & $23.94 \pm 6.6$ \\
\hline
\end{tabular}

p-value-0.0001 (highly significant).
The increase in the serum homocysteine levels, the urinary micro albumin gradually increased with a significant P-value - 0.0001. The mean serum homocysteine values are 14.64, 14, 16.32, 17.96 and $23.94 \mu \mathrm{mol} / \mathrm{L}$ when urine microalbuminuria is nil, trace, $1+, 2+$ and $3+$ respectively (Table 5 ).

Table 6: Comparison serum homocysteine and hemoglobin, hematocrit in study versus controls.

\begin{tabular}{|llll|}
\hline & HB(g/dl) & $\begin{array}{l}\text { PCV } \\
(\text { vol\%) }\end{array}$ & $\begin{array}{l}\text { Mean S. } \\
\text { Homocysteine } \\
(\mu \mathrm{mol} / \mathrm{L})\end{array}$ \\
\hline $\begin{array}{l}\text { Study } \\
\text { group }\end{array}$ & $9.54 \pm 1.15$ & $31.55 \pm 3.37$ & $17.54 \pm 5.34$ \\
\hline $\begin{array}{l}\text { control } \\
\text { group }\end{array}$ & $9.97 \pm 1.32$ & $32.54 \pm 3.57$ & $7.59 \pm 1.91$ \\
\hline P-value & $0.015 \mathrm{SG}$ & $0.045 \mathrm{SG}$ & $<0.0001 \mathrm{HS}$ \\
\hline
\end{tabular}

S-Significant, HS- Highly significant

The Table 6 shows the mean values of hemoglobin, hematocrit (PCV) and serum homocysteine levels in the study group and the control group with a significant $p$ value.

Table 7: Mode of delivery- study vs controls.

\begin{tabular}{|llll|}
\hline Mode of delivery & $\begin{array}{l}\text { Study } \\
\text { group }\end{array}$ & $\begin{array}{l}\text { Control } \\
\text { group }\end{array}$ & Total \\
\hline Caesarean section & 27 & 14 & 41 \\
\hline Vaginal delivery & 73 & 86 & 159 \\
\hline Total & $\mathbf{1 0 0}$ & $\mathbf{1 0 0}$ & $\mathbf{2 0 0}$ \\
\hline
\end{tabular}

p-value $<0.0001$ significant.

The Table 7 shows that the rate of caesarean section was significantly raised in women with pregnancy related hypertensive disorders when compared to women in the control group.

Table 8: S. Homocysteine and perinatal outcome: study versus controls.

\begin{tabular}{|lllll|}
\hline Perinatal outcome & $\begin{array}{l}\text { Study group } \\
(\mathbf{N})\end{array}$ & $\begin{array}{l}\text { Mean Homocysteine } \\
(\mu \mathrm{mol} / \mathrm{L})\end{array}$ & $\begin{array}{l}\text { Control group } \\
(\mathbf{N})\end{array}$ & $\begin{array}{l}\text { Mean Homocysteine } \\
(\boldsymbol{\mu m o l} / \mathrm{L})\end{array}$ \\
\hline Normal growth & 43 & $16.23 \pm 3.67$ & 94 & $7.61 \pm 1.90$ \\
\hline SGA & 9 & $16.84 \pm 3.61$ & 4 & $8.08 \pm 2.55$ \\
\hline IUGR & 41 & $17.34 \pm 5.32$ & 2 & $6.15 \pm 1.77$ \\
\hline IUD & 4 & $29.2 \pm 6.38$ & 0 & \\
\hline Still birth & 3 & $25.53 \pm 6.11$ & 0 & \\
\hline
\end{tabular}

The Table 8 shows the perinatal outcomes among the PIH cases and normal pregnant women and the correlation between maternal serum homocysteine levels. It was observed that normal growth was seen in 43 women in study group and 94 in control group.
SGA in 9 cases in study group and 4 cases in control group. IUGR in 41 women in study group and 2 women in control group. IUD among 4 women in study group and still birth in 3 cases among the study group. 
Maternal serum homocysteine levels have a direct relationship in predicting the severity of pre-eclampsia and perinatal outcome. The mean serum homocysteine values are rising there is an adverse perinatal outcome among the women with pregnancy related hypertensive disorders).

\section{DISCUSSION}

High blood pressure in pregnant women is associated with decreased placental function (placental insufficiency) resulting in fetal malnutrition and reduced fetal growth. ${ }^{5}$

Elevated plasma homocysteine concentrations is an independent risk factor for peripheral vascular diseases and coronary artery diseases. It is also associated with arterial damage by interfering with the cellular oxygenation, resulting in a formation of harmful free radicals. ${ }^{6}$

The present study aimed to find the role of hyperhomocysteinemia as one of the etiologic factors of pregnancy related hypertensive disorders.

Maternal age is one of the essential risk factors associated with pregnancy related hypertensive disorders. Young women of less than 20 years and women over 30 years are more prone for development of pre-eclampsia. $^{7}$ Studies have shown that serum homocysteine increase with age from 20 to 29 years till 40-49 years. However, there was a slight decline in serum Hcy levels noted at older age groups of 50-60 years. Changes in renal function, impaired renal metabolism of homocysteine, vitamin status, or both may be responsible in part for the age-related changes in homocysteine concentration. ${ }^{8}$

Levels of maternal serum Homocysteine normally decreases with gestational age and are lowest in the second trimester. ${ }^{9}$ This is either due to the physiological response to the pregnancy, increase in estrogen, hemodilution from increased plasma volume or increased demand for methionine by both the mother and fetus. ${ }^{10}$

A study done by Mansour A et al, showed that there is no significant correlation of homocysteine levels in relation to gestational age among pre-eclamptic women. The present study is in par with the above study. ${ }^{11}$

Hyperhomocysteinemia leads to hypertension and cardiovascular diseases through homocysteine mediated damage to vascular smooth muscle and endothelial cells. This damage further leads to a loss of arterial vasodilation, vascular integrity, and thus increased blood pressure (BP) and accelerated atherosclerosis. The observation of an increased prevalence of hypertension in persons with raised serum homocysteine levels, together with the demonstration that lowering homocysteine levels appeared to result in a reduction of blood pressure, anchors the evidence that hyperhomocysteinemia is a risk factor for hypertension.

Study done by Khosrowbeygi et al, showed a significant raise in the SBP of the study group $(150.67 \pm 1.91)$ compared to controls $(109.00 \pm 1.11)$ showing same pattern of serum Homocysteine levels in study $(14.05 \pm 1.43)$ and controls $(6.38 \pm 2.58)$ with a significant p-value. ${ }^{12}$

The present study is in accord with the above study showing the raise of SBP and serum homocysteine levels in women with pregnancy related hypertensive disorders compared to normotensive pregnant women with a significant $\mathrm{p}$-value $<0.0001$.

The studies done by Ferdausi $\mathrm{M}$ et al, Khosrowbeygi A et al, have shown a positive correlation between SBP and homocysteine levels with a significant P-value. The present study also shows a positive correlation $(r=0.311$, $\mathrm{p}=0.002$ ) with significant $\mathrm{P}$-value agreeing with the above studies.

In studies done by Khosrowbeygi A, Ferdausi $\mathrm{M}$ et al, showed a significant raise of DBP and serum Homocysteine levels in both groups with a significant $p$ value. The present study also showed same pattern with raised DBP in study group $(97.20 \pm 8.17)$ compared to controls $(73.57 \pm 6.7)$ as found in the above studies with a significant $\mathrm{P}$-value.

The studies done by Ferdausi et al, and Khosroweygi et al, have shown a positive correlation between the maternal serum homocysteine levels and diastolic blood pressure with significant P-value. The present study also shows a positive correlation between serum Homocysteine and DBP with significant " $\mathrm{r}$ " value 0.543 and $p$-value $<0.0001$ agreeing with the above studies.

Seema B et al, and Noto et al, showed a significant raise in MAP of study group compared to controls showing same pattern of raise in serum homocysteine levels between both the groups with a significant $\mathrm{p}$-value. ${ }^{13,14}$

The present study is in accord with the above studies showing raise of MAP and serum homocysteine levels in women with pregnancy related hypertensive disorders compared to normotensive pregnant women with a significant $\mathrm{p}$-value.

The studies done by Seema B et al and Noto R et al, have shown a positive correlation between serum homocysteine levels and MAP with a significant P-value. The present study shows a positive correlation with significant $\mathrm{p}$-value $(\mathrm{r}=0.832 \mathrm{p} \leq 0.0001)$ agreeing with the above studies.

Elevated circulating of homocysteine is a risk factor of endothelial dysfunction and vascular diseases such as atherosclerosis and occlusive disorders. The vascular 
effects of hyperhomocysteinemia have been proposed to include endothelial cell injury and thrombus formation. Maternal hyperhomocysteinemia is associated with a number of placenta-mediated diseases such as preeclampsia and eclampsia. Homocysteine appears to be the missing link in etiology of preeclampsia.

Many authors have studied serum homocysteine levels in women with pregnancy related hypertensive disorders. All the above studies by Ferdausi M et al, Khosrobeygi et al, Miglani S et al, Raijmakers MT et al, Sanlikan F et al, Monsour A et al, have shown a significant rise of serum homocysteine levels in the study group when compared to the controls. ${ }^{15-18}$ The present study shows consistent findings in par with the above studies with a significant $\mathrm{p}$-value.

On the contrary, the studies done by Zeeman $\mathrm{G}$ et al, and Hietala $\mathrm{R}$ et al, have shown insignificant relation between serum homocysteine levels in study versus controls whereas, the present study values indicate a significant difference. ${ }^{19,20}$

A positive association is expected to exist between the serum homocysteine levels and severity of pre-eclampsia. Studies done by Ferdausi et al, Sanlikan et al, and Kanan Avinash et al, have shown that serum homocysteine levels are higher in women with severe pre-eclmapsia when compared to women with mild pre-eclampsia indicating a direct relationship between serum homocysteine concentration and severity of preeclampsia.

The present study findings are in par with the above studies showing higher serum homocysteine values in severe pre-eclampsia $(20.59 \pm 4.4)$ compared to mild preeclampsia $(15.17 \pm 1.90)$ with a significant $\mathrm{p}$-value < 0.0001 .

However, on the contrary, study done by Miglani S et al, differs from the above studies indicating insignificant relation of homocysteine with severity of pre-eclmapsia.

Serum creatinine concentrations were significantly higher in pre eclamptic women as compared to controls. This is probably due to reduced renal perfusion and glomerular filtration rate, secondarily to abnormal glomerular morphology, i.e, endotheliosis in pre-eclampsia. Since nearly $70 \%$ of homocysteine elimination is dependent on renal uptake and metabolism of homocysteine, altered renal function might be responsible for hyperhomocystenemia in pre-eclampsia. Raised serum uric acid levels indicate renal involvement by increased tubular reabsorption, decreased tubular secretion and diminished renal flow. High level of serum uric acid is found to correlate with the severity of pre-eclampsia, volume contraction and fetal jeopardy.

Studies done by Ferdausi M et al, Sanlikan F et al, shows a significant rise in serum uric acid levels in study group when compared to control group. The present study shows findings consistent with those of other studies with a statistical significance of $\mathrm{p}<0.0001$.

Uric acid impairs nitric oxide generation in the endothelial cells inducing endothelial dysfunction. Besides the reduced clearance, hyperuricemia in preeclampsia may be due to increased uric acid production caused by trophoblast breakdown, cytokine release and ischemia. Uric acid can cause endothelial dysfunction, damage and inflammation, which leads to oxidation. Elevated circulating homocysteine is also a risk factor for endothelial dysfunction and vascular diseases such as atherosclerosis and occlusive vascular disorders.

As per the study done by Ferdausi $\mathrm{M}$ et al, there was a positive correlation between serum Uric acid and homocysteine levels in pre-eclampsia. The present study also shows a positive correlation in the same respect with significant $\mathrm{P}$-value (" $\mathrm{r}$ " $=0.258$ and $\mathrm{p}=0.01$ ).

Lactic dehydrogenase (LDH) is an intracellular enzyme that converts lactic acid to pyruvic acid, and elevated levels indicate cellular death and leakage of the enzyme from the cell. High levels of LDH indicates the severity of pre-eclampsia.

A study conducted by Sanlikan F et al, showed the rise of serum LDH in the pre eclamptic women when compared to the control group. In the present study the finding is consistent with raised LDH level in study group $(550.33 \pm 132.36)$ compared to control group $(370.50 \pm 106.92)$ with a significant ' $p$ ' value $<0.0001$.

To best of our knowledge, no studies were found comparing serum homocysteine levels with serum LDH levels in women with pregnancy related hypertensive disorders.

The present study made an attempt to correlate serum Homocysteine levels with serum LDH in pre eclamptic women. This study indicates that there is a positive correlation between homocysteine and LDH indicating that LDH levels can be taken into consideration with regard to severity of pre-eclampsia where facility for homocysteine estimation are not available.

Microalbuminuria is a marker of renal injury that can be detected earlier than any notable decline in the glomerular filtration rate. Studies have shown that hyperhomocysteinemia leads to glomerular injury and activates mitogen MAP kinases and induces endoplasmic reticulum stress in cultured meningeal cells. Homocysteine stimulates ceramide-mediated redox signaling and increases monocyte chemo attractant protein-1 expression in the kidney via nuclear factorkappa B activation. These studies suggest that hyperhomocystinemia may play a causative role in early renal injury. ${ }^{21}$ 
The studies conducted by Seema Bibi et al, and Amal Mansour et al, have shown a positive correlation between microalbuminuria and serum homocysteine levels in pre eclamptic women. ${ }^{11}$ The present study also shows positive correlation in par with above studies with a significant P-value. Homocysteine is a potent excitatory neurotransmitter that binds to the N-methyl-D- aspartate (NMDA) receptor and also leads to oxidative stress, cytoplasmic calcium influx, cellular apoptosis, and endothelial dysfunction. There are a lot of researches which put in evidence that oxidative stress in uteroplacental tissues with an important role in the development of placental-related diseases. Few authors have pointed that hypoxia is necessary to maintain stem cells in a fully pluripotent state. Physiological level of reactive oxygen species regulates the transcription factors. In normal pregnancies, the earliest stages of the fetus development take place in physiological hypoxia. This protects the developing fetus against the deleterious and teratogenic effects of reactive oxygen species (ROS). ${ }^{22}$

The studies done by Miglani S et al, Laskowska $\mathrm{M}$ et al, and Urban $\mathrm{J}$ et al, showed no significant correlation between the maternal serum Homocysteine levels and the perinatal outcome..$^{23,24}$

On the contrary, the studies done by Urban $\mathrm{J}$ et al, Vollset $\mathrm{S}$ et al, and Bergen et al, have concluded that higher homocysteine concentration in early pregnancy has higher risk of adverse pregnancy outcome. ${ }^{25,26}$ The present study found adverse pregnancy outcomes like IUD, still birth with increased levels of serum homocysteine levels. ${ }^{27,28}$

\section{CONCLUSION}

Elevated homocysteine levels can be due to genetic or multifactorial deficit or a combination of both. Nutritional defects involve inadequate intake of folic acid and vitamin B12.

Elevated homocysteine concentration injures the vascular endothelium, thereby contributing to the pathology of pregnancy related hypertensive disorders.

Elevated levels of homocysteine can be reduced by administering vitamins which help by increasing the metabolism of homocysteine. The internationally accepted treatment for hyperhomocystenemia is using a combination of folic acid $400 \mu \mathrm{g}$, vitamin B12 $500 \mu \mathrm{g}$ and pyridoxine $10 \mathrm{mg}$ initiating from pre-conceptional period, as these deficiencies are very often seen in our population.

\section{Funding: No funding sources} Conflict of interest: None declared

Ethical approval: The study was approved by the Institutional Ethics Committee

\section{REFERENCES}

1. Baumann MU, Bersinger NA, Surbek DV.Serum markers for predicting preeclampsia. Mol Aspects Med. 2007;28:227-44.

2. Hasanzadeh M, Ayatollahi H, Farzadnia M, Ayati S, Khoob MK. Elevated plasma total homocysteine in preeclampsia. Saudi Med J. 2008;29(6):875.

3. Yelikar K, Deshpande S, Kulkarni M. Association of maternal serum homocysteine level with severity of preeclampsia: A case control study. Int J Reprod Contracep Obstet Gynecol. 2016;5:2713-7.

4. Ferdausi M, Khatun M, Yusuf MA, Rahman A, Rahman Z. Association between high serum homocystine and preeclampsia. J Shaheed Suhrawardy Med College. 2013;5(1):21-5.

5. Falco M, Pollio F, Scaramellino M, Pontillo M, Lieto AD. Homocysteinemia during pregnancy and placental disease. Clin Exp Obstet Gynecol. 2000;27:188-90.

6. Cotter AM, Molloy AM, Scott JM, Daly SF. Elevated plasma homocysteine in early pregnancy: a risk factor for the development of severe preeclampsia. Am J Obst Gynecol. 2001;185(4):7815.

7. Kumari N, Dash K, Singh R. Relationship between maternal age and preeclampsia. IOSR J Dental Med Sci. 2016;15(12):55-7.

8. Lakshmikumar K, Gomti KD, Shugeta ND, Arbind RS. Effect of age on serum homocysteine level among adult urban population of Manipur. J Med Society. 2013;27(1):46.

9. Walker MC, Smith GN, Perkins SL, Keely EJ, Garner PR. Changes in homocysteine levels during normal pregnancy. Am J Obst Gynecol. 2016;180(3):660-4.

10. Yelikar KA, Deshpande SS, Kulkarni ML. Association of maternal serum homocysteine level with severity of pre-eclampsia: a case control study. IJRCOG. 2016;5(8):2713-7.

11. Mansour A, Harb H, Abdelhafeez M. Diagnostic value of homocysteine and other preeclampsia markers: relationship with severity. Int J Biol Chem. 2011;5:227-37.

12. Khosrowbeygi A, Ahmadvand H. Circulating levels of homocysteine in preeclamptic women. Bangladesh Med Res Council Bulletin. 2011;37(3):106-9.

13. Qureshi SB, Ahmad M, Qureshi PM, Memon A, Qazi RA. Hyperhomocysteinemia, vascular related pregnancy complications and the response to vitamin supplementation in pregnant women in Pakistan. $\mathbf{J}$ Pak Med Assoc. 2010;60(9):741-5.

14. Noto R, Neri S, Noto Z, Cilio D, Abate G, Noto P, Pepi F, Leanza A, Molino G. Hyperhomocysteinemia in preeclampsia is associated to higher risk pressure profiles. European Review Med Pharmacol Sci. 2003;7:81-7.

15. Miglani S, Nautiyal R, Prakash A. Hyperhomocysteinemia in pre-eclampsia: is routine 
screening rational? Int $\mathrm{J}$ Repro Contracep Obst Gynecol. 2006;6(4):1272.

16. Raijmakers MT, Zusterzeel PL, Steegers EA, Peters WH. Hyperhomocysteinaemia: a risk factor for preeclampsia? European J Obst Gynecol Reprod Biol. 2001;95(2):226-8.

17. Sanlikan F, Tufan F, Gocmen A. The evaluation of homocysteine level in patients with preeclampsia. Ginekol Pol. 2015;86:287-91.

18. Giguere Y, Charland M, Bujold E, Bernard N, Grenier S, Rousseau F, Lafond J, Légaré F, Forest JC. Combining biochemical and ultrasonographic markers in predicting preeclampsia: a systematic review. Clinical Chemistry. 2010;56(3):361-75.

19. Zeeman GG, Alexander JM, McIntire DD, Devaraj S, Leveno KJ. Homocysteine plasma concentration levels for the prediction of pre-eclampsia in women with chronic hypertension. Am J Obstet Gynecol. 2003;189:574-6.

20. Hietala R, Turpeinen U, Laatikainen T. Serum homocysteine at 16 weeks and subsequent preeclampsia. Obstet Gynacol. 2001;97:527-9.

21. Wenlin MA, Ruhui LIU, Lin LI. The relationship between micro albuminuria and plasma homocysteine level in chinese patients with hypertension. J Hypertens. 2014;3:5.

22. Micle O, Muresan M, Antal L, Bodog F, Bodog A. The influence of homocysteine and oxidative stress on pregnancy outcome. J Med Life. 2012;5(1):68.

23. Laskowska M, Oleszczuk J. Homocysteine in pregnancies complicated by preeclampsia with and without IUGR: a comparison with normotensive pregnant women with isolated IUGR and healthy pregnant women. Open J Obst Gynecol. 2011;1:1916.

24. Urban J, Jrochi S, Bielechi D, Urban RE. Serum homocysteine and nitric oxide levels in pregnancy complicated with intrauterine fetal growth restriction. Archives Perinatal Med. 2007;13(3):27-9.

25. Vollset SE, Refsum H, Irgens LM, Emblem BM, Tverdal A, Gjessing HK, et al. Plasma total homocysteine, pregnancy complications, and adverse pregnancy outcomes: the hordal and homocysteine study. Am J Clinical Nutrit. 2000;71(4):962-8.

26. Bergen NE, Jaddoe VW, Timmermabs S, Hofman A, Lindemans J, Russcher H. Homocysteine and folate concentrations in early pregnancy and the risk of adverse pregnancy outcomes: the generation study. BJOG. 2012;119(6):739-51.

27. Basak SK, Begum K, Rashid M, Yasmin N, Begum $\mathrm{H}$. Haematocrit value in preeclampsia. Bangladesh $\mathrm{J}$ Obstet Gynaecol. 2015;30(2):80-5.

28. Sirdah MM, Yassin MM, Shekhi SE, Lubbad AM. Homocysteine and vitamin B 12 status and iron deficiency anemia in female university students from Gaza Strip, Palestine. Revista Brasileira Hematologia Hemoterapia. 2014;36(3):208-12.

Cite this article as: Hymavathi K, Shukla N, Sreeleena Madhuri PV. Correlation of serum homocysteine levels in pregnancy related hypertensive disorders versus normotensive pregnancies. Int J Reprod Contracept Obstet Gynecol 